University of Nebraska - Lincoln

DigitalCommons@University of Nebraska - Lincoln

$5-28-2020$

\title{
Coronavirus Food Assistance Program for Crops Producers
}

Bradley Lubben

University of Nebraska-Lincoln, blubben2@unl.edu

Follow this and additional works at: https://digitalcommons.unl.edu/ageconfarmmgmt

Part of the Agribusiness Commons, Agriculture Law Commons, Entrepreneurial and Small Business Operations Commons, Management Information Systems Commons, Other Business Commons, and the Other Economics Commons

Lubben, Bradley, "Coronavirus Food Assistance Program for Crops Producers" (2020). Extension Farm and Ranch Management. 37.

https://digitalcommons.unl.edu/ageconfarmmgmt/37

This News Article is brought to you for free and open access by the Agricultural Economics Department at DigitalCommons@University of Nebraska - Lincoln. It has been accepted for inclusion in Extension Farm and Ranch Management by an authorized administrator of DigitalCommons@University of Nebraska - Lincoln. 


\title{
Coronavirus Food Assistance Program for Crops Producers
}

\author{
By Brad Lubben
}

May 28, 2020

Congress and the President have approved multiple phases of COVID-19 assistance to date including the \$2.3 trillion CARES (Coronavirus Aid, Relief, and Economic Security) Act passed in March that provides financial support for agricultural producers as a small part of the overall relief.

While agricultural producers and agribusinesses are eligible for two programs administered through the Small Business Administration, including the Paycheck Protection Program (PPP) and Economic Injury Disaster Loans (EIDLs), the primary support for agriculture is coming from USDA through the Coronavirus Food Assistance Program (CFAP). The CARES Act provided $\$ 9.5$ billion directly to the Secretary of Agriculture and provided $\$ 14$ billion in funding to replenish Commodity Credit Corporation (CCC) accounts. The Secretary has used the $\$ 9.5$ billion of CARES Act funding and $\$ 6.5$ billion to date of CCC funding to implement CFAP.

The CFAP program rolled out with rules and sign-up through USDA's Farm Service Agency (FSA) in late May. The program provides direct payments to producers of a range of crops and livestock based on market losses from January to April and continuing disruptions in the wake of the COVID-19 pandemic. Since the CFAP program utilizes both the CARES Act funding and CCC funding, the program includes multiple payment rates in the calculation of total support for a producer.

\section{Crops}

CFAP provides substantial support to crop producers for economic losses from price declines on sales as well as market disruptions. Of the total $\$ 16$ billion in estimated assistance, most is slated to go to livestock, but a large portion will go to producers of specialty and non-specialty crops. In general CFAP provides assistance to specialty and non-specialty crops for which the relevant futures or cash price declined at least $5 \%$ from mid-January to mid-April along with additional assistance for specialty crops that could not be sold due to market disruptions The details and payment rates are unique to both categories and are described below with payment rates shown in Tables 1 and 2.

- Non-Specialty Crops (Grains, Oilseeds, and Cotton). Payments cover "eligible inventory" equal to the lesser of a producer's unpriced inventory as of January 15, 2020 or $50 \%$ of 2019 production.

$\circ$ The first portion of the payment is calculated at a rate equal to $50 \%$ of the price decline for the commodity from mid-January to mid-April and is paid on $50 \%$ of eligible inventory. For corn as an example, the first payment rate is $\$ 0.32$ per bushel on $50 \%$ of eligible inventory.

- The second portion of the payment is calculated at a rate equal to $55 \%$ of the mid-January to mid-April price decline and is also paid on $50 \%$ of the eligible inventory. For corn 
again, the second payment rate is $\$ 0.35$ per bushel on $50 \%$ of eligible inventory.

- Based on the first and second payments each paid on $50 \%$ of eligible inventory, one can also average the two payment rates to get an effective rate payable on $100 \%$ of eligible inventory for a simple estimation of total payments. For corn in the example, the effective payment rate is $\$ 0.335$ per bushel on $100 \%$ of eligible inventory.

- Specialty Crops (Fruits, Vegetables, Tree Nuts). Assistance for specialty crops is split into three separate payment depending on the type of loss experienced. While payment rates vary by category of loss, documentation will be critical to determine production and the amount of production potentially eligible for each category of assistance.

- Price Loss. The first payment is for specialty crops that suffered a price loss of at least $5 \%$ between mid-January and mid-April. The payment is calculated as $80 \%$ of the price decline multiplied by producer sales during the same timeframe.

- Spoilage. The second payment is for specialty crops that were shipped from the farm to a buyer, but could not be sold and spoiled due to a lack of a market (as documented by the buyer). The payment is equal to $30 \%$ of the crop's sales value multiplied by the volume shipped and spoiled.

- Unshipped Production. The third payment is for specialty crops that were unharvested or unshipped from the farm due to a lack of market buyers and were not nor will be sold. The payment is equal to an expected $5.875 \%$ of the crop's value multiplied by the volume of unharvested and/or unshipped crops.

\section{Sign-up and Analysis}

While sign-up for CFAP began on May 26 and is on-going through August 28 through FSA offices, there may still be some questions to be answered along the way. USDA addressed one of initial questions with additional guidance on marketing contracts that do and don't qualify in terms of inventory that was unpriced as of January 15. Inventory is not eligible if it was covered by marketing contracts that lock in a cash or futures price or a minimum cash. This would rule out most hedging tools other than basis contracts or delayed/deferred pricing contracts. The ineligible contracts generally eliminate price risk, or at least the risk of futures market declines from which market losses were calculated in the first place to determine assistance.

The mechanics and math can be complicated, but FSA has produced a spreadsheet tool that can be used to calculate potential payments and apply for assistance. Details are available on USDA's CFAP website at farmers.gov/cfap. The downloadable Excel spreadsheet payment calculator is available through a link on this page or directly at the following UNL shortcut: go.unl.edu/fsacfaptool. The payment calculator will allow producers to plug in appropriate numbers for production, sales, and inventory to automate the calculations and estimate total payments across all commodities. 
A simplified example provides insight on the calculation and methodology:

2019 corn production: 200,000 bushels

January 15, 2020 inventory: 160,000 bushels

Portion of corn inventory unpriced as of January 15, 2020: 75\%

Eligible inventory $=$ lesser of unpriced inventory or $50 \%$ of 2019 production

$=$ lesser of $(75 \% * 160,000)$ or $(50 \% * 200,000)$

$=100,000$ bushels

Part 1 payment $=$ eligible inventory ${ }^{*}$ payment rate ${ }^{\star} 50 \%=100,000 * \$ 0.32 * 50 \%=\$ 16,000$

Part 2 payment $=$ eligible inventory ${ }^{*}$ payment rate ${ }^{\star} 50 \%=100,000 \star \$ 0.35 * 50 \%=\$ 17,500$

Gross payment $=$ part 1 payment + part 2 payment $=\$ 16,000+\$ 17,500=\$ 33,500$

While the calculator will provide estimates of total payments, there are some important limitations to these estimates. Because overall funding is limited at present, the CFAP payment is structured into two parts, with an initial payment of $80 \%$ due upon approval and the remaining $20 \%$ paid later subject to potential prorating of payments if there are insufficient funds to cover the full amount.

Producers are also subject to payment eligibility, payment limit, and conservation compliance rules.

- Eligibility. Producers must have an average adjusted gross income from 2016-2018 of less than $\$ 900,000$ unless at least $75 \%$ of the AGI comes from farming, ranching, or forestry.

- Payment Limits. Producers are subject to an individual payment limit of $\$ 250,000$ across all eligible CFAP commodities (including crops and livestock). Corporate entities that normally face a single payment limit under other FSA programs have a special rule for CFAP assistance that increases the payment limit to $\$ 250,000$ times the number of shareholders that contribute substantial labor or management (at least 400 hours per year) up to a limit of 3 shareholder or $\$ 750,000$.

- Conservation compliance. As with other USDA farm programs, producers must be in compliance with conservation requirements including conservation of highly erodible lands and wetlands.

Considering the payment rules and payment structure, the above example can be continued:

$$
\begin{aligned}
\text { Maximum gross payment } & =\text { lesser of gross payment or payment limit } \\
& =\text { lesser of } \$ 33,500 \text { or } \$ 250,000 \text { (assuming one individual) }
\end{aligned}
$$


Initial payment $=$ maximum gross payment ${ }^{\star} 80 \%=\$ 33,500 * 80 \%=\$ 26,800$

Potential remaining payment $=$ maximum gross payment ${ }^{\star} 20 \%=\$ 33,500 * 20 \%=\$ 6,700$

Based on some general estimates of eligible crops and livestock in Nebraska, total CFAP payments could exceed more than $\$ 1$ billion, with a substantial portion due to crop producers before any payment eligibility or limits are factored in.

Looking ahead, producers are assured of the initial $80 \%$ of the payment with at least a portion of the remaining 20\% to come. There are already efforts to pass another round of COVID-19 assistance in Congress. If additional assistance comes as widely expected, it could ensure full payments on the current CFAP program as well as pave the way for further assistance on additional 2020 production affected by on-going market losses.

In sum, the CFAP assistance will definitely help producers hurt by market price declines and market disruptions in the wake of the COVID-19 pandemic. The estimated $\$ 1$ billion of potential assistance will increase cash flow on the farm and ranch and will represent a major part of the farm income bottom line this year, but will certainly not make up for the full extent of market losses to date nor cover continued losses and challenges for the remainder of the 2020 production and marketing year. Watching for further legislative development will be a key part of the financial picture going forward.

Table 1. CFAP Crop Assistance Payment Rates

\begin{tabular}{|l|c|c|c|c|}
\hline Commodity & $\begin{array}{c}\text { Unit of } \\
\text { Measure }\end{array}$ & $\begin{array}{c}\text { CARES Payment } \\
\text { Rate on 50\% of } \\
\text { Eligible } \\
\text { Inventory }\end{array}$ & $\begin{array}{c}\text { CCC Payment } \\
\text { Rate on 50\% of } \\
\text { Eligible } \\
\text { Inventory }\end{array}$ & $\begin{array}{c}\text { Effective } \\
\text { Payment Rate } \\
\text { on 100\% of } \\
\text { Eligible } \\
\text { Inventory }\end{array}$ \\
\hline Barley, Malting & bushel & $\$ 0.34$ & $\$ 0.37$ & $\$ 0.355$ \\
\hline Canola & pound & $\$ 0.01$ & $\$ 0.01$ & $\$ 0.01$ \\
\hline Corn & bushel & $\$ 0.32$ & $\$ 0.35$ & $\$ 0.335$ \\
\hline Upland Cotton & pound & $\$ 0.09$ & $\$ 0.10$ & $\$ 0.095$ \\
\hline Millet & bushel & $\$ 0.31$ & $\$ 0.34$ & $\$ 0.325$ \\
\hline
\end{tabular}




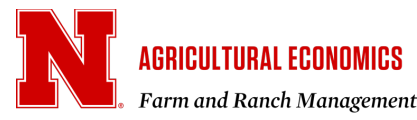

\begin{tabular}{|l|c|c|c|c|}
\hline Oats & bushel & $\$ 0.15$ & $\$ 0.17$ & $\$ 0.16$ \\
\hline Sorghum & bushel & $\$ 0.30$ & $\$ 0.32$ & $\$ 0.31$ \\
\hline Soybeans & bushel & $\$ 0.45$ & $\$ 0.50$ & $\$ 0.475$ \\
\hline Sunflowers & pound & $\$ 0.02$ & $\$ 0.02$ & $\$ 0.02$ \\
\hline Wheat, Durum & bushel & $\$ 0.19$ & $\$ 0.20$ & $\$ 0.195$ \\
\hline Wheat, Hard Red Spring & bushel & $\$ 0.18$ & $\$ 0.20$ & $\$ 0.19$ \\
\hline
\end{tabular}


Table 2. CFAP Specialty Crop Assistance Payment Rates

\begin{tabular}{|c|c|c|c|}
\hline Commodity & $\begin{array}{l}\text { CARES Payment Rate } \\
\text { (Price Losses on Sales) }\end{array}$ & $\begin{array}{l}\text { CARES Payment Rate } \\
\text { (Shipped but Spoiled } \\
\text { Product) }\end{array}$ & $\begin{array}{l}\text { CCC Payment Rate } \\
\text { (Unharvested and/or } \\
\text { Unshippped Product) }\end{array}$ \\
\hline & \multicolumn{3}{|c|}{$(\$ / \mathbf{l b})$} \\
\hline Almonds & $\$ 0.26$ & $\$ 0.57$ & $\$ 0.11$ \\
\hline Apples & - & $\$ 0.18$ & $\$ 0.03$ \\
\hline Artichokes & $\$ 0.66$ & $\$ 0.49$ & $\$ 0.10$ \\
\hline Asparagus & - & $\$ 0.38$ & $\$ 0.07$ \\
\hline Avocados & - & $\$ 0.14$ & $\$ 0.03$ \\
\hline Beans & $\$ 0.17$ & $\$ 0.16$ & $\$ 0.03$ \\
\hline Blueberries & - & $\$ 0.62$ & $\$ 0.12$ \\
\hline Broccoli & $\$ 0.62$ & $\$ 0.49$ & $\$ 0.10$ \\
\hline Cabbage & $\$ 0.04$ & $\$ 0.07$ & $\$ 0.01$ \\
\hline Cantaloupe & - & $\$ 0.10$ & $\$ 0.02$ \\
\hline Carrots & $\$ 0.02^{*}$ & $\$ 0.11$ & $\$ 0.02$ \\
\hline Cauliflower & $\$ 0.11$ & $\$ 0.31$ & $\$ 0.06$ \\
\hline Celery & - & $\$ 0.07$ & $\$ 0.01$ \\
\hline Corn, sweet & $\$ 0.09$ & $\$ 0.13$ & $\$ 0.03$ \\
\hline Cucumbers & $\$ 0.13$ & $\$ 0.15$ & $\$ 0.03$ \\
\hline Eggplant & $\$ 0.07$ & $\$ 0.15$ & $\$ 0.03$ \\
\hline Garlic & - & $\$ 0.85$ & $\$ 0.17$ \\
\hline Grapefruit & - & $\$ 0.11$ & $\$ 0.02$ \\
\hline Kiwifruit & - & $\$ 0.32$ & $\$ 0.06$ \\
\hline
\end{tabular}




\begin{tabular}{|c|c|c|c|}
\hline Lemons & $\$ 0.08$ & $\$ 0.21$ & $\$ 0.04$ \\
\hline Lettuce, iceberg & $\$ 0.20$ & $\$ 0.15$ & $\$ 0.03$ \\
\hline Lettuce, romaine & $\$ 0.07$ & $\$ 0.12$ & $\$ 0.02$ \\
\hline Mushrooms & - & $\$ 0.59$ & $\$ 0.11$ \\
\hline Onions, dry & $\$ 0.01$ & $\$ 0.05$ & $\$ 0.01$ \\
\hline Onions, green & - & $\$ 0.30$ & $\$ 0.06$ \\
\hline Oranges & - & $\$ 0.14$ & $\$ 0.03$ \\
\hline Papaya & - & $\$ 0.32$ & $\$ 0.06$ \\
\hline Peaches & $\$ 0.08$ & $\$ 0.32$ & $\$ 0.06$ \\
\hline Pears & $\$ 0.08$ & $\$ 0.18$ & $\$ 0.03$ \\
\hline Pecans & $\$ 0.28$ & $\$ 0.93$ & $\$ 0.18$ \\
\hline Peppers, bell type & $\$ 0.14$ & $\$ 0.22$ & $\$ 0.04$ \\
\hline Peppers, other & $\$ 0.15$ & $\$ 0.22$ & $\$ 0.04$ \\
\hline Potatoes & - & $\$ 0.04$ & $\$ 0.01$ \\
\hline Raspberries & - & $\$ 1.45$ & $\$ 0.28$ \\
\hline Rhubarb & $\$ 0.15$ & $\$ 1.03$ & $\$ 0.20$ \\
\hline Spinach & $\$ 0.37$ & $\$ 0.37$ & $\$ 0.07$ \\
\hline Squash & $\$ 0.72$ & $\$ 0.39$ & $\$ 0.08$ \\
\hline Strawberries & $\$ 0.84$ & $\$ 0.72$ & $\$ 0.14$ \\
\hline Sweet potatoes & - & $\$ 0.18$ & $\$ 0.04$ \\
\hline Tangerines & - & $\$ 0.22$ & $\$ 0.04$ \\
\hline Taro & - & $\$ 0.23$ & $\$ 0.05$ \\
\hline Tomatoes & $\$ 0.64$ & $\$ 0.38$ & $\$ 0.07$ \\
\hline
\end{tabular}




\begin{tabular}{|l|c|c|c|}
\hline Walnuts & - & $\$ 0.45$ & $\$ 0.09$ \\
\hline Watermelons & - & $\$ 0.02$ & - \\
\hline
\end{tabular}

Brad Lubben is an extension associate professor and policy specialist in the Department of Agricultural Economics. 


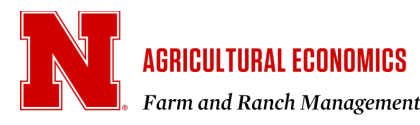

\begin{tabular}{|l|c|c|c|}
\hline Walnuts & - & $\$ 0.45$ & $\$ 0.09$ \\
\hline Watermelons & - & $\$ 0.02$ & - \\
\hline
\end{tabular}

Brad Lubben is an extension associate professor and policy specialist in the Department of Agricultural Economics. sexual orientation, gender identity, religion, disability, age, genetic information, veteran status, marital status, and/or political affiliation in its programs, activities, or employment. 